\title{
PERAN ATRIBUT PRODUK DAN MEDIA SOSIAL TERHADAP KEPUTUSAN PEMBELIAN WARDAH DI PALU
}

\author{
Hasmawati \\ Zakiyah Zahara \\ Program Studi S1 Manajemen, Fakultas Ekonomi dan Bisnis, Universitas Tadulako \\ Email: Hasmawati249@gmail.com;Zakiyah66.zm@gmail.com;
}

\begin{abstract}
The research Sims to determine the rope of Product Attributes and Social media on Purchasing Decisions to buy Wardah Brand Cosmetics In Palu City. This type of research ia casual serearch. The independent variable ia the Product attribute $\left(X_{1}\right)$ and Social media $\left(X_{2}\right)$, while the dependent variable ia the purchase decision $(Y)$. The collection methods used were questionnaire, literatur study, and interview. The sampling technique used purposive sampling with a sample size of 120 respondents. The data analisys method used multiple linear regression, $F$ test and $t$ test. Product attribute and social media simultaneously have significant effect towards purchasing decisions of Wardah's Customers in Palu, Product attribute partially has significant effect towards purchasing decision, as well as social media partially has significant effect towards purchasing decision of Wardah's Customers in Palu.
\end{abstract}

Keywords: Product Attributes, Social Media, and Purchasing Decision.

\begin{abstract}
ABSTRAK
Penelitian ini bertujuan untuk mengetahui peran atribut produk dan media sosial terhadap keputusan pembelian kosmetik merek Wardah di Kota Palu. Jenis penelitian ini merupakan penelitian kausal. Variabel independen adalah atribut produk $\left(\mathrm{X}_{1}\right)$ dan media sosial $\left(\mathrm{X}_{2}\right)$, sedangkan variabel dependen adalah keputusan pembelian (Y). Metode pengumpulan yang digunakan adalah kuesioner, studi kepustakaan, dan wawancara. Teknik penarikan sampel menggunakan purposive sampling dengan jumlah sampel sebanyak 120 responden. Metode analisis data menggunakan regresi linear berganda, uji F dan uji t. Variabel atribut produk, media sosial secara simultan bepengaruh signifikan terhadap keputusan pembelian Wardah di Kota Palu, variabel atribut produk secara parsial berpengaruh terhadap keputusan pembelian Wardah di Kota Palu, dan variabel sosial media secara parsial berpengaruh terhadap keputusan pembelian Wardah di Kota Palu.
\end{abstract}

Kata Kunci: Atibut Produk, Media Sosial, dan Keputusan Pembelian.

\section{PENDAHULUAN}

Perkembangan industri kosmetik di Indonesia saat ini tergolong cukup baik, Sekarang kecantikan bukan hanya menjadi sebuah keinginan melainkan menjadi kebutuhan masyarakat terutama kaum wanita yang semakin sadar akan pentingnya kosmetik sebagai kebutuhan sehari-hari. Kosmetik merupakan produk yang ditawarkan agar dapat mgemenuhi kebutuhan dan keinginan mendasar wanita akan kecantikan, kosmetik seringkali menjadi sarana bagi konsumen untuk memperjelas identitas dirinya secara sosial dimata masyarakat. Kosmetik mempunyai kemampuan yang berbeda dalam memenuhi kebutuhan dan keinginan konsumen. Oleh karena itu konsumen harus berhati-hati dalam membeli produk kosmetik yang ditawarkan agar memperoleh kepuasan maksimum. Sebagian wanita menganggap bahwa kosmetik merupakan suatu kebutuhan yang wajib dimiliki. Hal inilah yang menyebabkan muncul dan bersaingnya perusahaan-perusahan kosmetik yang berskala besar maupun kecil. Untuk menghadapi persaingan tersebut, maka perusahaan kosmetik harus mampu menciptakan sebuah inovasi baru yang dapat memberikan kepuasan bagi konsumen itu sendiri baik dari segi 
kualitas, merek, harga dan atribut produk yang lain sehingga dengan demikian konsumen dapat menentukan pilihannya.

Konsumen menentukan pilihan terhadap suatu produk biasanya melihat atribut produk yang melekat pada produk yang ditawarkan. Atribut produk dapat menjadi pembeda pada suatu produk, sehingga memberikan nilai tambah, manfaat serta menjadi bahan pertimbangan dalam pengambilan keputusan pembelian. Atribut produk mempunyai pengaruh besar pada persepsi pembeli terhadap produk, selain membedakan suatu produk dengan produk lain, atribut produk juga mampu menjadi daya tarik konsumen. Atribut produk adalah unsur-unsur produk yang dipandang penting oleh konsumen dan dijadikan dasar dalam pengambilan keputusan pembelian, atribut produk meliputi kualitas produk, fitur, desain, dan sebagainya (Tjiptono, 2008).

Wardah merupakan salah satu merek produk kecantikan yang ada di Indonesia. Produsen kosmetik perawatan kulit dan wajah ini diprakarsai oleh PT Paragon Technology and Innovation (PTI), dengan beragam produk wardah dipersembahkan bagi kaum wanita yang ingin mendapatkan perawatan tubuh yang aman serta lengkap. Kosmetik wardah adalah produk kecantikan buatan indonesia yang aman dan berkualitas tinggi dengan memproduksi ragam kosmetik untuk bermacam kondisi kulit misalnya pelembab untuk kulit berminyak ataupun kosmetik yang cocok pada kulit kering, berjerawat, dan lainlain agar konsumen dapat memilih produk yang sesuai dengan jenis kulitnya. Kosmetik merek Wardah aman bagi kulit karena terbuat dari bahan-bahan alami terpercaya dan telah mendapatkan sertifikat halal dari MUI.

PT. Paragon Technology and Innovation (PTI), terus melakukan inovasi melalui pemasaran modern, yang tidak hanya sekedar memasarkan produk yang berkualitas, membuat produk dengan harga murah dan menempatkan produk yang mudah dijangkau konsumen tetapi perusahaan juga melakukan komunikasi dengan cara memperkenalkan produk mereka secara intensif melalui iklan televisi dan iklan media sosial. Iklan merupakan bentuk komunikasi tidak langsung yang didasari pada informasi tentang keunggulan atau keuntungan suatu produk yang disusun sedemikian rupa sehingga menimbulkan rasa menyenangkan yang akan merubah pikiran seseorang untuk melakukan pembelian. Iklan adalah bentuk promosi yang paling banyak digunakan perusahaan dalam mempromosikan produknya (Tjiptono, 2008).

Seiring dengan perkembangan teknologi saat ini internet menjadi salah satu media yang memberikan banyak manfaat dan kemudahan bagi semua orang dalam memenuhi kebutuhannya. Pemasaran dengan strategi berbasis internet merupakan salah satu alat yang dapat dimanfaatkan oleh perusahaan untuk menyampaikan informasi yang dibutuhkan oleh pelanggan untuk melakukan pemilihan produk. Memasarkan atau memperjual belikan suatu produk lewat internet disebut dengan pemasaran elektronik (e-marketing) atau pemasaran online (online marketing).

Media sosial merupakan bagian yang penting dalam melakukan strategi penjualan, pelayanan komunikasi, dan pemasaran yang lebih besar dan lebih lengkap serta mampu menyesuaikan diri dengan pasar. Menurut Kotler dan Keller (2016) Media sosial adalah sarana bagi konsumen untuk berbagi informasi teks, gambar, audio, dan video satu sama lain dengan perusahaan, dan sebaliknya. Memanfaatkan teknologi yang ada merupakan salah satu cara inovatif untuk mendekatkan perusahaan kepada konsumen. Mengingat perkembangannya yang sangat cepat, media sosial dapat menjadi media paling stategis bagi perusahaan untuk menjangkau konsumen. PT Paragon Technology and Innovation mengiklankan produknya melalui media sosial seperti youtobe, instagram, facebook, twitter dan lainlain untuk mengiklankan produknya.

Berdasarkan latar belakang di atas, maka penulis tertarik untuk mengangkat suatu karya tulis ilmiah untuk menyampaikan ke masyarakat agar mengenal lebih jauh tentang produk merek Wardah dan apa 
saja yang berperan terhadap keputusan konsumen untuk membeli dan menggunakan produk merek Wardah yang khususnya yang berada di kota Palu. Maka dari itu penulis mengangkat judul "Peran atribut produk dan media sosial terhadap keputusan konsumen membeli kosmetik merek Wardah di Kota Palu."

\section{KAJIAN LITERATURDAN KERANGKA PEMIKIRAN}

Pemasaran merupakan kegiatan utama yang di lakukan perusahaan agar dapat mempertahankan kelansungannya. Kegiatan pemasaran perusahaan harus mampu memberi kepuasan kepada konsumen dengan cara memberikan produk atau barang yang berkualitas, sehingga konsumen akan memberikan tanggapan yang baik terhadap perusahaan. Menurut Kotler dan Keller (2016) pemasaran adalah kegiatan yang dilakukan untuk pemenuhan keperluan pengguna. Melalui berbagai cara serta memberi keuntungan semua orang. Dengan demikian, segala bentuk kegiatan perusahaan yang di lakukan dikordinir agar puaskan pengguna dan nantinya memberi keuntungan.

Kotler dan Amstrong (2014) menyatakan bahwa pemasaran merupakan suatu cara atau proses yang di lakukan perusahaan agar saling membentuk ikatan dan nilai kepada pelanggan maupun perusahaan agar mendapat laba. Assauri (2010) Pemasaran ialah aktivitas yang dilakukan manusia guna memenuhi kebutuhan dan keinginannya melalui proses pertukaran. kegiatan dalam pemasaran untuk pemenuhan kebutuhan manusia dan sosial. Agar terus berkembang maka perusahaan harus melakukan pembaruan pada produk yang ditawarkan agar seperti harapan langganan.

Setiap perusahaan memiliki visi dan misi yang harus dicapai salah satunya adalah terjualnya seluruh produk yang mereka tawarkan dengan harapan memperoleh laba yang ditetapkan. Selain itu perusahaan juga menginginkan konsumennya merasa puas terhadap produk yang ditawarkan. Jika produk yang ditawarkan perusahaan mampu memuaskan kebutuhan dan keinginan konsumen maka konsumen akan terus menggunakan produk tersebut, hal ini menjamin kelangsungan perusahaan. Oleh karena itu perusahaan harus mampu membentuk sebuah konsep pemasaran dan manajemen pemasaran.

Menurut Kottler dan Keller (2016) menyatakan bahwa manejemen pamasaran ialah senian juga ilmu dalam menentukan target pasaran untuk bertahan, serta meningkatkan total langganan dengan menciptakan, memberikan, dan komunikasikan nilai pelanggan yang lebih diatas. Menurut Kotler dan Amstrong (2014) menyatakan bahwa manajemen pemasaran sebagai seni maupun ilmu yang memilih pemasar sebagai target utama untuk membangun ikatan dan saling memberi keuntungkan bersama. Assauri (2010) manajemen pamasaran meliputi aktivitas penganalisaan, perencanan, pelaksanaan, dan pengendalian sistem agar tercapai harapan perusahaan.

Produk merupakan komponen penting yang terdapat pada mix pemasaran. Besarannya harga yang ditetapkan tergantung dari nilai yang dimiliki oleh produk tersebut. Dalam hal ini atribut produk berperan penting terhadap nilai produk, jika semakin kuat manfaat maka makin besar nilanya produk.

Menurut Kotler dan Amstrong (2014) menyatakan bahwa produk merupakan segala sesuatu yang dapat di tawarkan pada pasar serta menarik perhatian, penggunaan, konsumsi juga memberi kepuasan dan kebutuhan calon langganan. Menurut Kotler dan Keller (2016) menyatakan bahwa prodak ialah suatu yang dapat ditawarkan pada pasar guna puaskan kemauan dan keperluan calon langganan. Menurut Tjiptono (2008) produk merupakan segala sesuautu yang dapat ditawarkan produsen untuk diperhatikan, diminta, dicari, digunakan, atau dikonsumsi pasar sebagai pemenuhan kebutuhan serta keinginan pasar yang bersangkutan

Penulis mendefinisikan produk sebagai suatu yang nampak maupun tidak tidak nampak yang bisa ditawarkan dan juga dikonsumsi oleh konsumen yang berupa produk barang maupun jasa yang dapat memberikan kepuasan bagi konsumen kan pemenuhan keperluan dan kemauanya. 
Atribut yang melekat pada setiap produk berbeda-beda, sehingga diharapkan agar konsumen lebih selektif lagi jika dalam memilih atau menentukan produk pilihannya. "Atribut prodak merupakan komponen unsur yang menjadi patokan dalam pengambilan keputusan (Tjiptono). Atribut produk yang melekat pada produk dapat menjelaskan atau menggambarkan dengan jelas tentang apa saja kelebihan produk kepada konsumen, hal ini menimbulkan pengaruh yang besar pada persepsi pembeli.

Menurut Kotler dan Amstrong (2014) menyatakan atribut produk merupakan sesuatu yang ada manfaatnya jika ditawarkan. Manfaat-manfaat tersebut di sampaikan melalui atribut produk seperti mutu, kelengkapan, gaya serta desain produknya. Menurut Daryanto.(2011) Atribut produk sebagai pengembangan produk dan jasa yang membutuhkan pendefenisian manfaat yang ditawarkan. Manfaat itu dituangkan kedalam atribut yang meliputi mutu, kelengkapan, gaya serta desainya produk. Atribut produk disimpulkan sebagai komponen penting dan melekat diproduk dimana atribut produk itu mampu menjelaskan mengenai keunggulan serta jadi pembeda antaranya dengan produk pesaingnya.

Media sosial adalah sebuah media online (daring) yang dimanfaatkan sebagai sarana pergaulan sosial secara online di internet. Pengguna media sosial dapat saling berkomunikasi, berinteraksi, berbagi, networking, dan berbagai kegiatan lainnya. Media sosial menggunakan teknologi berbasis website atau aplikasi yang dapat mengubah suatu komunikasi ke dalam bentuk dialog interaktif. Menurut Solis (2010) media sosial merupakan bagian penting dari strategi penjualan, pelayanan, komunikasi, dan pemasaran yang lebih besar dan lebih lengkap serta merefleksikan dan menyesuaikan diri dengan pasar dan orang-orang yang mengartikannya. Menurut Kotler dan Keller (2016) menyatakan bahwa "Social media are a means for consumers to share text, images, audio, and video information with each other and with companies, and vice versa.", diartikan sebagai media sosial ialah sarana bagi konsumen untuk berbagi informasi teks, gambar, audio, dan video satu sama lain dan dengan perusahaan, dan sebaliknya.

Menurut Kotler dan Keller (2016) media sosial memiliki tiga jenis yaitu: 1). Online Comunities and Forums (komunitas dan forum) Komunitas dan forum online hadir dalam berbagai bentukan maupun di buat konsumen dan juga kelompok konsumen tanpa kepentingan pabrik dan mendapat dukungan pabrik melalui satu sama lain posting. 2). Blog(blog), catatan harian online yang di buat baru secara bertahap dan menjadi saluran penting bagi $E_{-}$WOM. 3). Social Networks (Jejaring Social), Jejaring sosial telah menjadi kekuatan perlu dalam bisnis kekonsumen dari pemasaran bisnis-kebisnis. Jejaring sosial meliputi Facebook,terbesar di dunia; LinkedIn, yang berfokus pada para profesional yang berpikiran karier; dan Twitter, dengan pesan 140 karakter atau "tweet." Berbeda jaringan menawarkan manfaat yang berbeda untuk perusahaan, Misalnya, Twitter dapat menjadi sistem peringatan dini yang memungkinkan cepat respon, sedangkan Facebook memungkinkan penyelaman lebih dalam untuk melibatkan konsumen dengan cara yang lebih bermakna.

Menurut Solis (2010) bahwa terdapat 4C dalam menggunakan media sosial yaitu 1). Context, diartikan sebagai sebuah cerita maupun informasi berupa pesan. 2). Communication, diartikan sebagai cerita atau info agar pesan terasa nyaman tersampaikan pada langganan. 3). Collaboration, diartikan sebagai bentuk kerja bersama antara pabrik dan langanan dimedia sosial agar efektif juga efisen. 4). Connection, diartikan sebagai bentuk pertahanan hubungan yang sudah dibina dengan melakukan kegiatan yang sifat lama dan membuat penggunanya makin dekat pada perusahaan.

Kosumen sebagai stakeholder yang miliki berbagai karakrter yang beragam sehingga perusahaan harus mampu menarik minat atau membuat image baik pada produk yang di tawarkannya sehingga konsumen terdorong supaya membeli. Menurut Kotler dan Amstrong (2014) Tingkah laku pembeli mengacu pada sikap pembelian akhir konsumen, individu juga rumah tangga akan membeli barang dan jasa untuk mereka pakai sendiri. Menurut Kotler dan Keller (2016) Tingkah laku pembeli 
merupakan ilmu yang mempelajari tentang pribadi, kelompok dalam pemilihan, membeli memakai, dan menghabiskan barang atau jasa agar terpenuhi keperluan serta kemauan mereka.

Menurut Kotler dan Amstrong (2014) terdapat beberapa faktor-faktor yang mempengaruhi perilaku konsumen yaitu : 1). Faktor Budaya (culture factors) memiliki peran pada tingkah laku pembeli sehingga orang pasar perlu tahu peran budaya, subkultur, maupun kelas sosial membeli. 2). Faktor Sosial (social factors) semacam kelompok referensi, keluarga, peran juga status sosial mampu memberikan pengaruh terhadap keputusan untuk membeli. 3). Faktor Pribadi (personal factors) memengaruhi keputusan dalam membeli yaitu pembeli pekerja, umur, situasi, pola hidup dan kepribadian. 4). Faktor Psikologi (psychological factors) memengaruhi keputusan membeli terdiri dari motivasi, pendapat, pelajaran, kepercayaan, dan moral.

Konsumen sebagai stakeholder suatu perusahaan mempunyai perilaku dan persepsi yang berbedabeda. Konsumen dapat menentukan kelangsungan hidup perusahaan, karena itu perusahaan harus mampu mengambil hati atau membuat image baik tentang produk yang ditawarkan. Menurut Kotler dan Amstrong (2014) perilaku pembelian konsumen mengacu pada perilaku pembelian akhir konsumen, baik individu maupun rumah tangga yang membeli barang dan jasa untuk dikonsumsi sendiri. Menurut Kotler dan Keller (2016) perilaku konsumen adalah ilmu yang mempelajari tentang bagaimana individu, kelompok, dan organisasi dalam memilih, membeli, menggunakan, dan menghabiskan barang, jasa, ide, atau pengalaman untuk memenuhi kebutuhan dan keinginan mereka.

Kotler dan Amstrong (2014) menjelaskan bahwa terdapat beberapa faktor-faktor yang mempengaruhi perilaku konsumen yaitu 1). Faktor budaya (culture factors), memberikan pengaruh yang luas dan mendalam pada perilaku konsumen. Pemasar perlu memahami peran yang dimainkan oleh budaya, subkultur, dan kelas sosial pembeli. 2). Faktor sosial (social factors), perilaku konsumen juga dipengaruhi oleh faktor sosial, seperti kelompok referensi, keluarga, peran dan status sosial mempengaruhi perilaku pembelian. 3). Faktor pribadi (personal factors), keputusan pembeli juga dipengaruhi oleh karakteristik pribadi seperti pembeli pekerjaan, usia dan panggung, situasi ekonomi, gaya hidup, dan kepribadian dan konsep diri. 4). Faktor psikologi (psychological factors), pilihan pembelian seseorang selanjutnya dipengaruhi oleh empat faktor psikologis utama: motivasi, persepsi, pembelajaran, dan keyakinan dan sikap.

Pengambilan keputusan konsumen berbeda-beda, bergantung pada kemampuan pembelian yang rumit dan mahal mungkin melibatkan lebih banyak pertimbangan pembelian dan lebih banyak konsumen. Kotler dan Amstrong (2014) mengelompokkan jenis perilaku pembelian konsumen berdasarkan tingkat keterlibatan pembeli dan tingkat perbedaan diantara merek, yaitu: 1). Perilaku pembelian yang rumit (complex buying behavior), membutuhkan keterlibatan yang tinggi dalam pembelian dengan berusaha menyadari perbedaan-perbedaan yang jelas diantara merek yang ada. 2). Perilaku pembelian pengurangan ketidaknyamanan (dissionance reducing buying behavior), mempunyai keterlibatan yang tinggi dan konsumen menyadari hanya terdapat sedikit perbedaan diantara berbagai merek. 3). Perilaku pembelian karena ada kebiasaan (habitual buying behavior), konsumen membeli suatu produk berdasarkan kebiasaan, bukan berdasarkan kesetiaan terhadap merek produk, tetapi karena mereka sudah mengenal produk tersebut 4). Perilaku pembelian yang mencari variasi (variety seeking buying behavior), perilaku ini memiliki keterlibatan yang rendah, namun masih terdapat merek yang jelas.

\section{METODE PENELITIAN}

Jenis penelitian yang digunakan dalam penelitian ini adalah penelitian deskriptif kausal yang berusaha untuk mengevaluasi pengaruh dari variabel atribut produk dan media sosial terhadap keputusan pembelian. Lokasi penelitian ini dilakukan di Kota Palu, dengan cara membagikan 
kuesioner online karena mengingat jumlah konsumen yang membeli kosmetik merek Wardah tersebar dimana-mana.

Metode penarikan sampel yang digunakan dalam penelitian ini adalah non probability sampling atau semua populasi tidak memberi peluang atau kesempatan menjadi sampel, dengan mengambil tipe purposive sampling. purposive sampling adalah cara pengambilan sampel berdasarkan karakteristik tertentu. Hal ini dikarenakan tidak semua sampel memiliki kriteria yang sesuai dengan fenomena yang diteliti. Oleh karena itu penulis memilih teknik purposive sampling yang menetapkan pertimbanganpertimbangan dan kriteria-kriteria tertentu yang harus dipenuhi oleh sampel yang digunakan dalam penelitian ini. Adapun kriteria yang dijadikan sebagai sampel penelitian yaitu: 1. Responden yang memutuskan membeli ataupun menggunakan kosmetik merek Wardah, 2. Responden yang berumur diatas 17 tahun yang bersedia dan cakap untuk mengisi kuesioner, 3. Responden yang menggunakan media sosial.

Teknik pengumpulan data yang digunakan pada penelitian ini menggunakan kuesioner, studi kepustakaan, dan wawancara. Populasi dalam penelitian ini adalah seluruh konsumen yang menggambil keputusan membeli dan menggunakan kosmetik merek Wardah di Kota Palu. Jumlah populasi dalam penelitian ini adalah tidak terbatas karena tidak adanya data jumlah konsumen kosmetik merek Wardah di Kota Palu. Ukuran sampel merujuk pada teori Hair et. all. (2010), ukuran sampel yang ideal dan representatif tergantung pada jumlah item pertanyaan pada indikator penelitian dikalikan 5 sampai 20 jumlah. Jumlah pernyataan yang digunakan sebanyak 20 item. Berdasarkan pertimbangan tersebut maka peneliti menetapkan jumlah sampel dengan ketentuan $6 \times 20$ item pernyataan yaitu 120 responden. Metode penarikan sampel yang digunakan dalam penelitian ini adalah non probability sampling atau semua populasi tidak memberi peluang atau kesempatan menjadi sampel.

Kriteria asumsi klasik klasik sebagai berikut: 1). Uji normalitas dilakukan untuk menguji model regresi variabel dependen dan independent ataupun keduanya memiliki distribusi normal. 2). Uji multikolinieritas digunakan untuk menguji jika model regresi ditemukan adanya korelasi antara variabel independent. 3). Uji heterokedastisitas yaitu digunakan untuk mengetahui dalam model regresi terjadi ketidaksamaan variance dari residual satu pengamatan yang lain. Pengujian hipotesis dilakukan dengan menggunakan regresi linear berganda.

\section{HASIL DAN PEMBAHASAN}

Penelitian ini menggunakan analisis regresi linear berganda dengan tujuan untuk membuktikan hipotesis yang telah diajukan, yaitu variabel bebas meliputi atribut produk dan media sosial secara simultan maupun parsial berpengaruh signifikan terhadap keputusan pembelian kosmetik Wardah di Kota Palu. Adapun tingkat kepercayaan yang digunakan dalam penelitian ini untuk menghitung pengaruh dengan menggunakan analisis regresi linear berganda yaitu tingkat kepercayaan $95 \%$ dengan tingkat signifikan $\alpha<0,5$.

Tabel 1 Hasil Uji Analisis Regresi Berganda

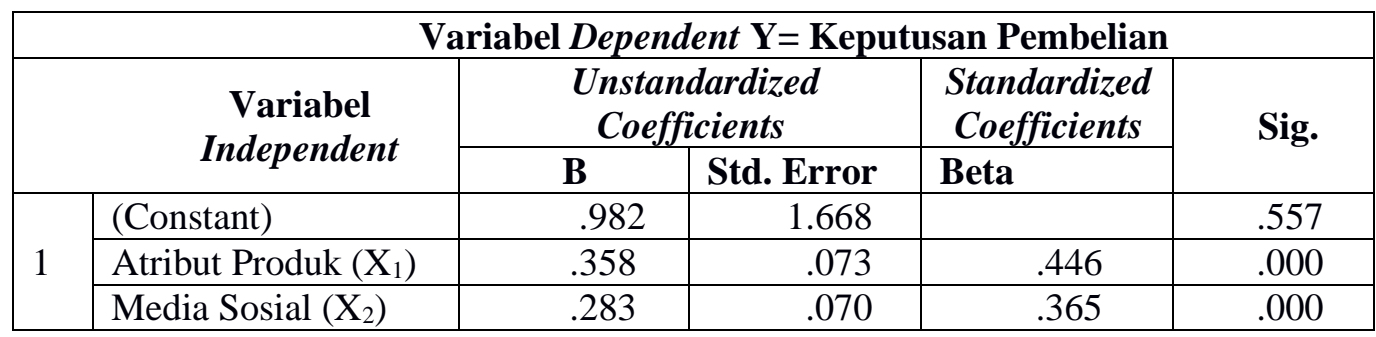




\begin{tabular}{|ll|}
\hline Sig F $=0,000^{\mathrm{a}}$ & \\
Multiple R & $=0,759^{\mathrm{a}}$ \\
R Square & $=0,576$ \\
Adjusted R Square & $=0,516$
\end{tabular}

Sumber: Data primer yang diolah, 2019

Berdasarkan tabel 4 di atas, dapat ditulis dalam bentuk persamaan regresi linear berganda. Untuk lebih jelasnya bentuk persamaan tersebut dapat dilihat sebagai berikut:

\section{$\mathrm{Y}=\mathbf{0 , 9 8 2}+\mathbf{0 ,}, 358 \mathrm{X1}+\mathbf{0 ,}, 283 \mathrm{X2}$}

Penjabaran di atas menunjukkan bahwa variabel independent yang dianalisis yaitu variabel atribut produk $\left(\mathrm{X}_{1}\right)$ dan media sosial $\left(\mathrm{X}_{2}\right)$ memberikan pengaruh positif terhadap variabel dependent (Y), yaitu keputusan pembelian kosmetik Wardah di Kota Palu. Untuk lebih jelasnya penjelasannya bentuk persamaan tersebut dapat dilihat berikut ini:

1. Nilai konstanta sebesar 0,982, artinya jika variabel independent (atribut produk dan media sosial) bernilai 0 atau konstan, maka variabel dependen (keputusan pembelian) nilainya sebesar 0,982.

2. Nilai koefisien regresi variabel atribut produk $\left(X_{1}\right)$ sebesar 0,358 , yang artinya jika variabel atribut produk $\left(\mathrm{X}_{1}\right)$ mengalami peningkatan maka keputusan pembelian juga akan meningkat.

3. Nilai koefisien regresi variabel media sosial $\left(\mathrm{X}_{2}\right)$ sebesar 0,283 , yang artinya jika variabel media sosial $\left(\mathrm{X}_{2}\right)$ mengalami peningkatan maka keputusan pembelian juga akan meningkat.

Tahap selanjutnya adalah menguji signifikan hubungan atau uji $\mathrm{F}$ antara variabel atribut produk $\left(\mathrm{X}_{1}\right)$ dan media sosial $\left(\mathrm{X}_{2}\right)$ terhadap keputusan pembelian $(\mathrm{Y})$.

Berdasarkan Tabel 5 di atas diperoleh Sig F yaitu 0,000, artinya nilai tersebut lebih kecil dibandingkan dengan nilai yang disyaratkan yaitu $\alpha=0,05$ dengan tingkat kepercayaan $95 \%$. Maka dapat dinyatakan bahwa secara simultan variabel atribut produk dan media sosial berpengaruh signifikan terhadap keputusan pembelian kosmetik Wardah di Kota Palu.

Hasil uji t digunakan untuk mengetahui apakah variabel $\left(\mathrm{X}_{1}, \mathrm{X}_{2}\right)$ secara parsial berpengaruh terhadap Y. Untuk lebih jelasnya hasil dapat dilihat pada tabel 6 berikut:

Dari hasil pengujian secara parsial (uji t) diketahui bahwa nilai signifikansi variabel atribut produk $\left(\mathrm{X}_{1}\right)$ adalah $0,000<\alpha=0,05$ dengan kata lain variabel atribut produk $\left(\mathrm{X}_{1}\right)$ berpengaruh signifikan terhadap keputusan pembelian (Y). Dengan demikian hipotesis yang menyatakan bahwa peran atribut produk berpengaruh signifikan terhadap keputusan konsumen membeli kosmetik merek Wardah di Kota Palu dapat diterima kebenarannya.

1. Hasil pengujian hipotesis $\mathrm{X}_{2}$ terhadap $\mathrm{Y}$

Dari hasil pengujian secara parsial (uji t) diketahui bahwa nilai signifikansi variabel media sosial $\left(\mathrm{X}_{2}\right)$ adalah $0,000<\alpha=0,05$ dengan kata lain variabel media sosial $\left(\mathrm{X}_{2}\right)$ berpengaruh signifikan terhadap keputusan pembelian (Y). Dengan demikian hipotesis yang menyatakan bahwa media sosial berpengaruh signifikan terhadap keputusan konsumen membeli kosmetik merek Wardah di Kota Palu" dapat diterima kebenarannya.

Sebelum akan melakukan pembelian biasanya konsumen melihat suatu produk sebagai kumpulan dari sifat dan ciri tertentu yang tercermin dari atribut yang melekat pada produk tersebut. Atribut produk tersebut antara lain adalah kualitas, merek dan desain. Pada umumnya, konsumen melihat atribut produk sebagai keseluruhan isi dari produk yang akan mereka beli. Atribut produk halal yang melekat pada kosmetik Wardah membangun perspektif dan keyakinan konsumen karena membuat konsumen merasa aman dalam memilih dan menggunakan kosmetik Wardah. variabel atribut produk sangat ditentukan oleh tiga dimensi yang pertama yaitu kualitas produk, dalam hal ini kosmetik Wardah merupakan kosmetik yang terjamin dari segi kualitas karena terbuat dari bahan-bahan alami sehingga dapat digunakan dalam jangka waktu yang lama. Selain itu kosmetik Wardah sudah terdaftar 
di badan pengawas obat dan makanan (BPOM) serta sudah mendapat sertifikat halal dari MUI. Dimensi kedua yaitu fitur produk kosmetik Wardah ini berbeda dengan kosmetik lain, karena memproduksi ragam kosmetik untuk bermacam kondisi kulit misalnya pelembab untuk kulit berminyak ataupun kosmetik yang cocok pada kulit kering, berjerawat, dan lain-lain agar konsumen dapat memilih produk yang sesuai dengan jenis kulitnya. Dimensi ketiga yaitu gaya dan desain produk kosmetik Wardah terkesan elegan karena bentuk wadah yang unik dan juga warna yang cerah dari tampilan kemasan. Oleh sebab itu variabel atribut produk berpengaruh terhadap keputusan pembelian.

Konsumen memulai proses pembelian suatu produk dari adanya kebutuhan, sehingga mereka akan mulai mencari informasi tentang produk yang dapat memberikan manfaat dan kegunaan yang maksimal bagi mereka. Informasi tersebut dapat mereka peroleh dari teman, tetangga, promosi, iklan, atau bahkan melakukan eksperimen melalui media sosial. Variabel media sosial sangat ditentukan oleh empat dimensi yang pertama yaitu context dalam penelitian ini yaitu penyampaian pesan melalui unggahan di akun media sosial Wardah baik di instagram, twitter, dan facebook terlihat menarik dengan adanya fitur dan perpaduan warna yang serasi dan caption mengenai produk sangat jelas, dengan adanya brand ambasador seperti Dewi Sandra, Zaskia Sungkar, dan Laudya Cintia Bella, yang juga menggunakan kosmetik merek Wardah membuat konsumen makin tertarik. Dimensi kedua communication yaitu dengan memposting produk kosmetik di akun media sosial Wardah sehingga konsumen tidak perlu datang ke outet jika ingin mencari tahu tentang produk apa yang ditawarkan dan apa keunggulan dari produk tersebut. Dimensi ketiga collaboration yaitu konsumen bisa berinteraksi dengan admin untuk lebih mengetahui manfaat produk yang ditawarkan di akun media sosial, selain itu konsumen bisa memberikan like di akun media sosial Wardah. Dimensi keempat connection yaitu bagaimana memelihara hubungan yang sifatnya berkelanjutan antara konsumen dan perusahaan PTI. Dalam hal ini konsumen dapat mencari kembali informasi mengenai produk dengan melakukan interaksi kepada admin di akun media sosial Wardah. Selain itu diadakan Giveaway bagi konsumen yang menjadi followers di akun media sosial Wardah yang menang akan diberi hadiah berupa kosmetik merek Wardah. Perusahaan PTI juga melakukan kegiatan amal diantaranya peningkatan kesejahraan masyarakat, sumbangan CSR dalam rangkaian acara tahunan, buka puasa bersama yatim dan dhuafa, pembagian paket sembako ramadhan, pengembangan seni dan kebudayaan, dan pembangunan potensi sumber daya manusia. Hal tersebut memberi makna bahwa perusahaan mampu memelihara hubungan yang baik dengan konsumen. Oleh sebab itu variabel media sosial berpengaruh terhadap keputusan pembelian.

\section{KESIMPULAN DAN SARAN}

\section{Kesimpulan}

Berdasarkan hasil penelitian yang telah diuraikan, maka diperoleh kesimpulan mengenai peran atribut produk dan media sosial terhadap keputusan konsumen membeli kosmetik merek Wardah di Kota Palu adalah sebagai berikut:

1. Variabel atribut poduk dan media sosial secara signifikan berpengaruh terhadap keputusan konsumen membeli kosmetik merek Wardah di Kota Palu.

2. Variabel tribut produk secara signifikan berpengaruh terhadap keputusan konsumen membeli kosmetik merek Wardah di Kota Palu.

3. Variabel media sosial secara signifikan berpengaruh terhadap keputusan konsumen membeli kosmetik merek Wardah di Kota Palu.

\section{Saran}


Berdasarkan hasil pembahasan dan kesimpulan yang diperoleh, maka saran yang dapat diberikan sebagai berikut :

1. Sebaiknya perusahaan Paragon Technologi and innovation agar mempertahankan kualitas produk dengan tetap menggunakan bahan-bahan alami sehingga lebih meningkatkan keputusan konsumen untuk membeli kosmetik merek Wardah.

2. Sebaiknya admin akun media sosial wardah lebih ramah dan lebih intens melakukan interaksi dengan konsumen agar lebih mengetahui manfaat dari kosmetik merek Wardah, sehingga dapat meningkatkan penjualan.

3. Kepada peneliti selanjutnya agar dapat mengembangkan penelitian ini dengan menggunakan metode lain dalam meneliti atribut produk dan media sosial terhadap keputusan konsumen, misalnya melalui wawancara mendalam terhadap responden, sehingga informasi yang diperoleh dapat lebih bervariasi dari pada angket yang jawabannya telah tersedia.

\section{REFERENSI}

Daryanto, 2011, Sari Kuliah Manajemen pemasaran, Bandung:PT Sarana Tutorial Nurani Sejahtera.

Ghozali, Imam, 2012. Aplikasi Analisis Multivariate dengan Program IBM SPSS. Yogyakarta : Universitas Diponegoro.

Hair, J. F., Jr., Black, W.C.,Babin, B. J. \& Anderson, R. E. 2010. Multivariate Data Analysis. $7^{\text {th }}$ ed., Prentice Hall, Upper Saddle River, N. J.

Kotler, Philip dan Amstrong, Gary, 2014. Principles of Marketing 12th Edition, Jilid 1 terjemahan Bob Sabran Jakarta : Erlangga.

Kotler, Philip dan Kevin Lane Keller, 2016. Marketing Managemen, 15th Edition, Pearson Education,Inc.

Solis, Brian. 2010. Engage The Complete Guide for Brand and Bussines to Build Cultive and Measure Succes In the New Web. New Jersey. John Mreys \& Sonscac.

Sugiyono, 2017. Metode Penelitian Kuantitatif, Kualitatif, dan R\&D. Bandung Alfabeta, CV.

Tjiptono, Fandy. 2008. Strategi Pemasaran. Edisi Ketiga. Yogyakarta. Penerbit Andi. 